\title{
SANCTUARY INFLUENCE IN CLASSICAL REPRESENTATIONS OF INCUBATION: THE MOTIF OF THE WITNESS AWAKE
}

\section{Francisco Barrenechea}

I. INTRODUCTION

\begin{abstract}
A PTOPHANEs' COMEDY Wealth, staged in 388 в.c.E., features a remarkable messenger speech describing a miracle cure by Asklepios (627-766), a narrative that has been thoroughly mined for information on the ritual of incubation practiced in the sanctuaries of the god. Scholars often remark on its similarity to the healing stories, or iamata, of Asklepios, but only Roos (1960) and Sineux (2006) have explored this connection in detail, specifically in relation to the Epidaurian iamata. ${ }^{1}$ Both narratives share a recognizable pattern that points to the presence of what Dorati and Guidorizzi (1996: 352) call a "cultural model," which they define as "a way of perceiving a phenomenon"-in this case incubation- "even before it is described." This model, they hold, was so pervasive that it survived relatively unchanged through late antiquity, down to the miracle cures of Christian saints. Scholarly work on the Epidaurian iamata over the last two decades has revealed the vital role the sanctuary played in shaping the model, but the comic messenger speech has only just begun to receive the attention it deserves. By "sanctuary," I refer to the personnel in charge of compiling, adapting, and publishing the narrative testimonies of the healings, with the intent of proclaiming the god's efficacy and expanding his worship. I provide additional evidence of this influence by examining what I will call the motif of the witness awake, that is, a witness of incubation who is not asleep during the ritual. This motif was pervasive as well: we find it in an Egyptian iama in honor of Imouthes-Asklepios (P. Oxy. XI 1381.91-140), which dates to the second century c.E., ${ }^{2}$ but it is already present in the Epidaurian and the comic healing stories, as well as in a third representation, Attic marble votive reliefs that depict incubation. In this article, I will examine how the motif found in these classical representations not only contributes to the religious function of the model by offering proof of the authenticity of the miracle, but also confirms belief in the philanthropic character of the god Asklepios, who makes himself accessible to all, be they dreaming or awake.

The three representations that will occupy us all date to roughly the same period: the Epidaurian iamata are the latest examples, having been inscribed in the second half of the fourth century B.C.E., though they collect material

${ }^{1}$ The first publication of the Epidaurian iamata already linked them to Aristophanes' messenger speech (Kavvadias 1883: 218).

${ }^{2}$ The Egyptian iama specifies that the witnessing took place in "neither a dream nor sleep" (oü $\tau$ '

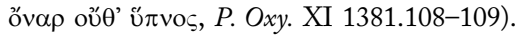

PHOENIX, VOL. 70 (2016) 3-4. 
that could date up to a century earlier; ${ }^{3}$ some of the stories could have already existed at the time of Aristophanes' Wealth. ${ }^{4}$ Yet years before this comedy was staged, votive reliefs with incubation scenes were being set up in the sanctuaries of Asklepios in Piraeus and Athens, which were founded in the late 420s B.C.E., and also in the sanctuary of Amphiaraos, where incubation was also practiced. The closeness in time of these representations offers an excellent opportunity to explore the influence of the sanctuary across various media, and in a particularly important period, that of the expansion of the cult of Asklepios from Epidaurus to Attica at the end of the fifth century B.C.E. This expansion points to the significance of Epidaurus and its newly established sanctuaries as important nodes for the shaping and transmission of the model.

Before I furnish an overview of these representations, a quick definition of the religious experience of incubation is needed. Incubation was a divinatory practice that consisted, as Dorati (2001: 91) succinctly puts it, "in seeking contact through dreams with a supernatural power, inside a sacred space, in order to obtain a healing, an oracle, or advice when faced with particularly important decisions." 5 This ritual was common, though not exclusive, to the sanctuaries of Asklepios. ${ }^{6}$ Those who practiced incubation sought access to knowledge beyond human ken to solve their immediate concerns; in the case of Asklepios, this knowledge was usually the god's outstanding medical expertise. The marvel of incubation, in contrast to other forms of divination, was that the consultants in need of treatment dealt directly with the god; ${ }^{7}$ they were the ones who took the initiative to invoke his presence and power. In this respect, the ritual practice is also considered a form of epiphany, since it involved a personal encounter with a manifested divinity. This vivid experience is what lies at the heart of the representations I will be considering.

\section{THE THREE REPRESENTATIONS}

\section{a. The Iamata}

I start with a survey of the Epidaurian iamata and how they manifest the influence of the sanctuary. ${ }^{8}$ Dorati and Guidorizzi (1996: 345) classify the iamata in general as "a specialized portion of the larger body of aretalogical literature"; their specific purpose is to testify to the power and excellence of the healer god. ${ }^{9}$

\footnotetext{
${ }^{3}$ For the dating of the sources, see LiDonnici 1995: 81-82.

${ }^{4}$ Aristophanes staged an earlier comedy with the same title in 408 в.c.E. For the relationship of this play to the second Wealth, see Sommerstein (2001: 28-33), who argues that the Wealth of 388 в.C.E. is a completely new creation, not a revised version of the earlier play as other scholars have argued.

${ }^{5}$ For the ritual per se, see von Ehrenheim 2015: 75-97.

${ }^{6}$ See Petridou 2015: 172-174 for other cults that used incubation.

7Johnston 2008: 90-91 and Suárez de la Torre 2009: 46.

${ }^{8}$ For sanctuary influence in the Epidaurian iamata, see Dillon 1994; Dorati and Guidorizzi 1996; Dorati 2001; Sineux 2007a; and Martzavou 2012.

${ }^{9}$ This function is also mentioned, for example, by Dillon (1994: 253-254) and Sineux (2006: 210).
} 
The Epidaurian iamata usually focus their narrative on the encounter with a deity in a dream vision and the benefit that results from it. Although narrative is common to dream divination, what distinguishes the Epidaurian iamata, as Downie (2013: 127) explains, is the "rhetoric of prescriptive clarity and therapeutic success." 10 The following stories from the Epidaurian iamata are typical examples: ${ }^{11}$

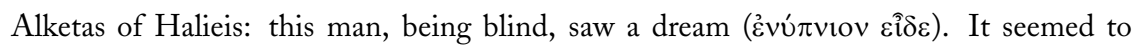

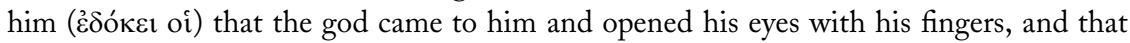

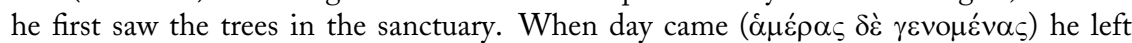
well. $\left(I G \mathrm{IV}^{2} 1,121.120-122=\mathrm{A} 18\right.$ LiDonnici $^{12}$

Kleinatas of Thebes, who had lice: this man, having a great multitude of lice on his

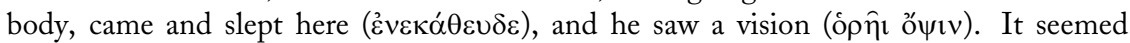

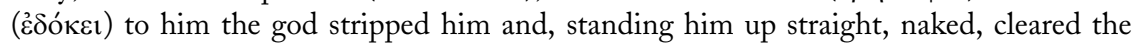

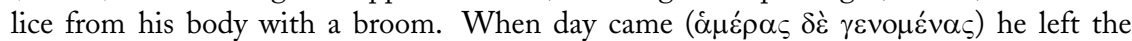
abaton well. $\left(I G \mathrm{IV}^{2} 1,122.45-49=\mathrm{B} 8(28) \text { LiDonnici }\right)^{13}$

The moment of incubation proper, when the consultant lies down to sleep,

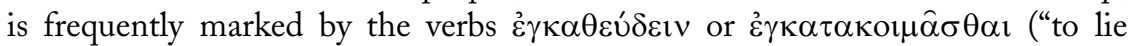
down"). Although these verbs can sometimes serve to introduce the dream

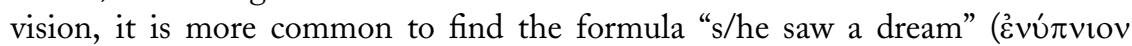

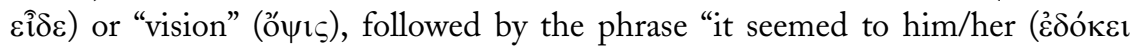
oi) that ...." This second clause presents the dream vision itself in the form of indirect discourse, relating the experience through the subjective perspective of the consultant. The iamata usually end with a reference to waking, such as

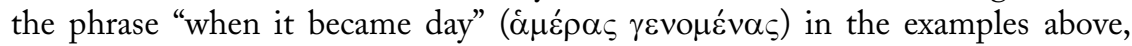
which marks the end of the dream state and the subjective perspective.

The Epidaurian collection of healing stories, the most complete that has survived from antiquity, was inscribed by a single hand in the second half of the fourth century в.C.E., a time when major rebuilding was being carried out in the sanctuary. ${ }^{15}$ The inscription is a compilation of existing written, visual, and

\footnotetext{
${ }^{10}$ For narrative and dream divination, see Downie 2014: 97-98. In contrast, the narratives of incubatory dreams of Aelius Aristides, for instance, present them as visions in need of interpretation; see Downie 2013.

${ }^{11} I G \mathrm{IV}^{2} 1,121-124$. Editions and commentaries of the Epidaurian iamata are offered by Herzog (1931) and LiDonnici (1995). See also Edelstein and Edelstein 1945: 1.423.

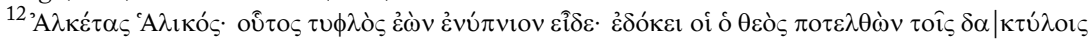

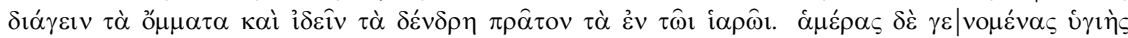
$\grave{\varepsilon} \xi \hat{\eta} \lambda \theta \varepsilon$. The reference numbers of LiDonnici (1995) are used in this article. The translation of this passage is mine; all other translations are from LiDonnici 1995, except where indicated.

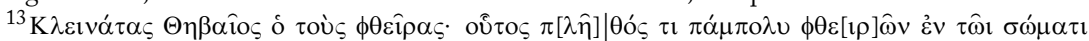

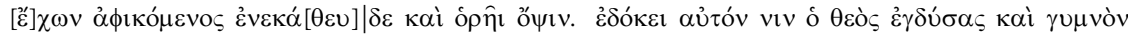

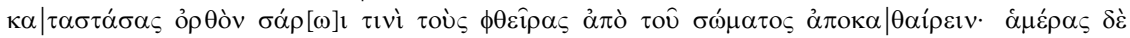

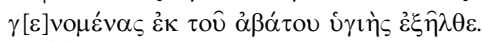

${ }^{14}$ Visions introduced by $\dot{\varepsilon} \gamma \kappa \alpha \theta \varepsilon v ́ \delta \varepsilon ı v$ or similar verbs are featured, for instance, in iamata A12, A15, and A19 LiDonnici.

${ }^{15}$ For the date of the inscription, see LiDonnici 1995: 17 and n. 13.
} 
oral testimonies of miracle cures, gathered from various sources, such as earlier inscriptions, votive reliefs, paintings, tablets, anatomical ex-votos, and other objects dedicated to the god. ${ }^{16}$ LiDonnici has tentatively identified thematic and stylistic groupings of stories in the iamata that point to the use of previous collections; she dates the earliest of these to about a century before the surviving collection. ${ }^{17}$ This short span, according to LiDonnici (1995: 82), would indicate that the compilations were a relatively recent phenomenon, and that the origin of these stories should be sought in the worshippers themselves and their "individual motivation" to share their experience, instead of in the sanctuary compilers. The variety of experiences portrayed in the iamata reflect these motivations, yet I believe that, through their selection and inscription of stories, the sanctuary personnel were instrumental in sanctioning and shaping the model of how to narrate, but also perceive, the religious experience.

The hand of the sanctuary may be detected, for instance, in the act of compilation itself. This action was not done mechanically or at random: the sanctuary adapted and embellished the tales that were already in existence, created new ones from existing objects and visual testimonies, and grouped them in meaningful ways. One can surmise that they did the same for the earlier collections. Their adaptations are clear when the iamata are compared, for instance, to the dedicatory inscriptions that served as their sources: the latter invariably focus on the act of dedication itself and very rarely mention the occasion, so further elaboration or embellishment would have been necessary to transform them into iamata. ${ }^{18} \mathrm{~A}$ few dedicatory objects might have facilitated the process by already featuring these tales: the first iama of the Epidaurian collection (A1 LiDonnici), for example, quotes a simple inscription which had been written, as the tale specifies, on a votive tablet (pinax): "Kleo bore a burden in her stomach

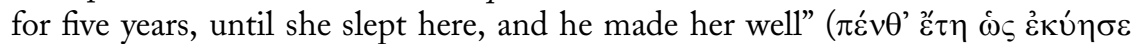

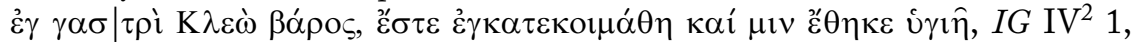
121.8-9). ${ }^{19}$ The compilers were also careful to include evidence for the authenticity of the tales: the mention of material objects as sources, as in the previous iama, is one example, but they also refer to witnesses, to which I will return below (262-270). ${ }^{20}$

By inscribing these stories on stelai in the abaton, the room where incubation took place, for all to read, the sanctuary molded the expectations of the wor-

\footnotetext{
${ }^{16}$ For a study of the sources on which the collection is based on, see LiDonnici 1995: 40-49; cf. Dorati and Guidorizzi 1996: 349-351. For healing stories associated with votive offerings, see iamata A1 and A15 LiDonnici. For the collection of oral accounts of incubations, see LiDonnici 1995: 50-60.

${ }^{17}$ LiDonnici 1995: 76-82.

${ }^{18}$ For the composition of Athenian votive inscriptions in the fourth century в.c.E., see Giovagnorio 2015: 80-85.

${ }^{19}$ See LiDonnici 1995: 44-45.

${ }^{20}$ See Dorati and Guidorizzi 1995: 361 and Sineux 2006: 204.
} 
shippers regarding the experience of incubation, giving them hopes that they would be cured, and constructed a certain image of the deity and his cult. ${ }^{21}$ At the same time, they instilled and perpetuated narrative motifs and formulas that helped the worshippers shape their own experience into an identifiable and even authoritative narrative form, whose familiarity helped confirm the truth of the lived experience. In this light, the brief inscription quoted in the very first iama of the Epidaurian collection could be understood as a programmatic gesture on the part of the sanctuary, instructing the readers of these tales to commemorate their successful cure by focusing on their experience with the god.

\section{b. Attic Reliefs Depicting Incubations}

Marble votive reliefs portraying incubation scenes are perhaps the earliest surviving representations of the practice; they appeared in Attica along with the cult of Asklepios, at the end of the 420s B.c.E., as well as in the sanctuary of Amphiaraos at Oropos, where incubation also took place. ${ }^{22}$ This form of commemoration testifies to the success and the familiarity of the practice in Athenian religious life at the time. Scholars now believe that Epidauros had a hand in the introduction of the cult and partly influenced the rituals of the new establishments, although there is no evidence that the sanctuary practice of compiling and publishing collections of iamata crossed the Saronic Gulf to Attica. ${ }^{23}$ Nevertheless, elements of the cultural model can be detected in these representations.

The iconography of these reliefs features incubation scenes: patients are depicted as lying down in the presence of the god, who treats them. ${ }^{24}$ This scene

${ }^{21}$ For the shaping of expectations, see for instance LiDonnici 1995: 18, 52; Martzavou 2012; for hope for a cure, LiDonnici 1992: 41; Dillon 1994: 240; von Ehrenheim 2015: 141; for the image of the god and the sanctuary, see Dorati 2001: 97. See in general von Ehrenheim 2015: 141-146.

${ }^{22}$ On the Athenian practice of setting up votive reliefs during this period, see Lawton 2009. Comella (2002: 46-48, 73-74, 103-104) offers a useful survey of this visual tradition, including the reliefs set up during the same period in the sanctuaries of Amphiaraos at Oropos (2002: 132-133) and Rhamnous (2002: 137). LiDonnici (1995: 42) and von Ehrenheim (2015: 108) note the abundance of votive reliefs in Athens compared to Epidauros.

${ }^{23}$ For the Epidaurian connection, see Clinton 1994; Parker 1996: 178; Wickkiser 2008: 90-105; Nutton 2013: 106-108. The Athenian Asklepieion did record individual dedications for administrative purposes, including the names of those who set them up, but not the stories associated with them; see Aleshire 1989: 103-110.

${ }^{24}$ Reliefs with this iconography: Athens, National Museum, inv. 1841 (LIMC Asklepios 54), 2373 (LIMC Asklepios 106), 2462 (Sudhoff 1926: pl. XII, fig. 11), 2489 (Sudhoff 1926: pl. XII, fig. 9), 3325 (Mitropoulou 1975: 40, fig. 15); Athens, Piraeus Museum, inv. 405 (Comella 2002: 73, fig. 65); Verona, Museo Maffeiano, no. 28615 (Sineux 2007b: 26, fig. 5); Kassel, Staatliche Kunstsammlungen, Sk. 44 (LIMC Asklepios 89); and a lost relief from Piraeus (see von Eickstedt 2001: 35 and fig. 19; an image is available in the Arachne database of the German Archaeological Institute: http://arachne.uni-koeln.de/item/objekt/174158 [accessed December 22, 2016]). The iconography is also found in reliefs from the sanctuaries of Amphiaraos: see Athens, National 
is usually accompanied by two others: in one, other worshippers (usually identified as the family of the patient) approach the god with offerings and gestures of acclamation; in the second, other divine companions of Asklepios appear along with him. ${ }^{25}$ Not all reliefs that commemorate the miracle healings of Asklepios feature an incubation scene: they can also simply display the worshipper approaching the god, an iconography that is more common to Attic reliefs of the period. When donors choose to depict an incubation scene in their commemorative reliefs, they seek to portray the efficacious treatment of the god for the purpose of acclaiming his power, as Sineux has observed; this highlighting of the treatment, he adds, matters more than any intent to portray a lived experience. ${ }^{26}$ In this respect, the reliefs can be related to the iamata, which also highlight the treatment and serve the same purpose. Building on the observations of Sineux, I suggest that there are other elements at play in these reliefs, besides the representation of effective treatment, which are also important for their aretalogical purpose. This article will consider one of these elements: the distinction between the subjective (dreaming) and the objective (waking) dimension of the experience of incubation, as a method of giving proof of the encounter, and thus of the power of the god. This distinction, which is found in the Epidaurian iamata and Aristophanes' messenger speech, is embodied in the motif of the witness awake.

Regarding the sanctuary's influence on these reliefs, Petsalis-Diomidis (2005: 213) suggests that the fact that these representations were set up in the precincts of the healing god would point to the temple administrators' authorization and endorsement of the iconography. One possible piece of evidence for this is provided by the so-called Telemachos monument, set up ca 400 в.c.E., which commemorated the foundation and early history of the Asklepieion on the south slope of the Athenian Akropolis. ${ }^{27}$ The main relief of this monument included a small representation of what is identified as an incubation relief. ${ }^{28}$ This image, as Sineux observes (2007b: 26), displays the iconography of these reliefs in its simplest form. Despite the monument's fragmentary state, the figure of the god is clear, reaching out his arm to the right. The figure of the recumbent patient is difficult to make out, but the bed is visible. The presence of this relief in the monument indicates a sanctuary of Asklepios, quite possibly the one in Piraeus, but what is revealing is the symbolic employment of this particular iconography:

Museum, inv. 3369 (reproduced here as fig. 1; see below, 266), and a fragment from the Oropos museum (LIMC Asklepios 111).

${ }^{25}$ Reliefs that include worshippers: Athens, National Museum inv. 3325; Kassel, Staatliche Kunstsammlungen Sk. 44. Reliefs that include both worshippers and divine companions: Athens, National Museum inv. 1841 and 2373; Piraeus Museum inv. 405; and the lost relief from Piraeus (for references, see above, n. 24). For recent overviews of the iconography, see Vikela 2004 and Sineux 2007b. For the iconography of Asklepios, see Holtzmann 1984.

${ }^{26}$ Sineux 2007b: 13, 15-16.

${ }^{27}$ For a recent description and discussion of the monument, see Wickkiser 2008: 67-72.

${ }^{28}$ Beschi 1982: 40-42. 
not only would it testify to the popularity of incubation, but more significantly, it would indicate a recognition of a familiar form of visually commemorating the experience of incubation in the god's sanctuaries at the time. ${ }^{29}$ In this light, the monument could be related to the programmatic purpose of the first iama of the Epidaurian collection, which also includes a miniature healing story inscribed in a pinax as a sample (and model) of the commemorations to be expected at the sanctuary.

\section{c. Messenger Speeches in Attic Comedy}

Just down the hill from the Athenian Asklepieion, comedies produced at the theater of Dionysus also offer evidence of the existence of the influence of the sanctuary in Athens. Wealth is not the only comedy to feature a healing story: Aristophanes' Amphiaraos (414 в.c.E.), as far as one can glimpse from its fragments, probably contained a iama that featured the epiphany of the god and a medical treatment. The core of the story was not very different from that of Wealth: ${ }^{30}$ a narrative snippet (Ar. fr. ${ }^{*} 21 P C G$ ) preserves the words of Amphiaraos addressing his daughter Iaso, which brings to mind the presence of Iaso as a companion of Asklepios in the messenger speech of Wealth (701). ${ }^{31}$ Another fragment, which mentions a female character preparing some sort of concoction (Ar. fr. $22 P C G$ ), may belong to the same narrative and could parallel Asklepios' preparation of a medicinal plaster in Wealth 716-718; this character could have been an attendant of the god like Panakeia, who accompanies Asklepios in Wealth 730-732. Since incubation was practiced in the cult of Amphiaraos as well, it is possible that a messenger also delivered an extended narrative of this religious experience. ${ }^{32}$ There is also some evidence that narratives of miracle cures were popular in comedy: for instance, Antiphanes (fr. 47 $P C G)$, who began his career a few years after Wealth was staged, related in his Asklepios a doctor's treatment of a patient with a chronic illness, the specialty of the god who gave the title to the comedy; it would not be much of a stretch to identify Asklepios with the healer in the fragment, as Kock has suggested. ${ }^{33}$

In contrast to the meager traces of Amphiaraos' miracle cure, the iama of Wealth is extensive and rich in detail. In this comedy, the personification of blind Wealth is laid down to incubate in the sanctuary of Asklepios, where the god restores his eyesight; this cure is reported back onstage, in a messenger

\footnotetext{
${ }^{29}$ For the motif of the votive tablet in these reliefs, see van Straten 1992: 254-260; Platt (2011: $45)$ notes their commemorative function.

${ }^{30}$ See Sineux 2007c: 201-202.

${ }^{31} \mathrm{We}$ know the line comes from a narrative because Amphiaraos' words are introduced by "he said" ( $\left.{ }^{\prime \prime} \lambda \varepsilon \xi(\varepsilon)\right)$.

${ }^{32}$ More tentatively, a third fragment from Amphiaraos (Ar. fr. 18 PCG), in which someone calls for a cushion and pillow to be brought out of a house, may also contain an allusion to incubation, as Kaibel noted. The words recall Chremylos' order to Karion in Wealth to bring bedding out of the house before they depart to incubate in Asklepios' sanctuary (624-626), which might point to a similar scene in the earlier play. See Ar. fr. $18 P C G$ for Kaibel's interpretation.

${ }^{33}$ See Antiphanes fr. $47 P C G$ for Kock's interpretation.
} 
speech, by a slave called Karion. Aristophanes' decision to have a messenger report the cure has less to do with the fact that a miraculous occurrence like this would conventionally take place off stage in Greek drama, and more with the fact that the incubatory experience was generally reported via narrative. ${ }^{34}$

This messenger speech shares important features with the later iamata. In addition to the expected focus on the incubatory experience, we find a similarity in form and content. ${ }^{35}$ But Aristophanes also introduces significant expansions and departures. While one could simply attribute these to the comic treatment of the material and the more extensive nature of the messenger narrative, a closer look reveals that they serve to stress and amplify the religious dimension of the reported event. Sineux (2006: 210) has observed that the messenger of Wealth, a slave called Karion, behaves much like the sanctuary personnel who "create a certain image of the divinity and ... favorable propaganda for the sanctuary" by means of the iamata they select and embellish. I would add that the humorous features of the narrative - for instance, a less than flattering portrayal of the god and the inclusion of his harsh treatment of an unpopular politician-serve to present the god as a type of comic hero, who practices his craft for the political benefit of the community. Aristophanes also externalizes the aretalogical function that the iamata leave implicit: Karion, as Sineux (2006: 210) notes, constructs a "veritable discourse on the divinity and his power" in his account of Asklepios' cure. I would also suggest that the joyous acclamation of the god by the narrator and his interlocutors at the end of the report further exemplifies this religious function: the slave praises (Ė nńvouv, 745) Asklepios' beneficial act, and his interlocutor, the wife of his master, immediately responds, "How great

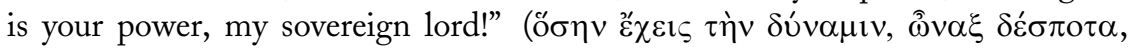
748). Sineux (2006: 203-204) adds that, in a similar fashion to the Epidaurian curators, the comic messenger seeks to make his story credible by emphasizing autopsy. But there is another important element of the narrative that is related to autopsy, and that is the motif of the witness awake, which is manifested in the role of Karion himself. As a messenger, his role is conventionally that of a witness, yet the sanctuary also deploys this role for its own purposes, and not only as a means of authenticating its tales, as we will see in the next section.

\section{THE WITNESS AWAKE}

Aristophanes' handling of the witness awake will provide the focal point for my study of the motif. It might seem remarkable to use a comic messenger speech, with its exaggerated and transgressive narrative of incubation, as comparative material to the Epidaurian iamata and Attic votive reliefs, whose con-

\footnotetext{
${ }^{34}$ See Sineux 2006: 209. For other scholarly work dedicated exclusively to this messenger speech, see Fernández (2000), who provides a structural analysis, and Tordoff (2012), who focuses on its paratragic elements.

${ }^{35}$ Sineux 2006: 203-206.
} 
tent was authorized for sanctuary display; yet the use of the motif in comedy finds surprising parallels in the other two sources. These affinities, I propose, can be ascribed to the sanctuary agenda regarding the portrayal of the god and his cult.

\section{a. A Transgressive Witness?}

The idea that the comic witness is a transgressive figure first needs to be explored. Initially, the narrator of the comic healing story seems very different from that of the Epidaurian iamata. In contrast to the latter, which adopts the point of view of the consultant to relate the dream vision, the comic messenger does not adopt Wealth's perspective of whatever it was he dreamt; the audience only has access to Karion's perspective of the events that took place during incubation. But this narrator is not dreaming, and even he indicates, in his report, the boundaries of sleeping and waking by noting, among other markers, the temple servant's injunction to "go to sleep" ( $\pi \alpha \rho \eta \gamma_{\gamma} \varepsilon\llcorner\lambda \varepsilon v \vee \kappa \alpha \theta \varepsilon v$ $\delta \varepsilon v v, 669)$ and the "getting up" of Wealth (738). Karion, moreover, explicitly states that

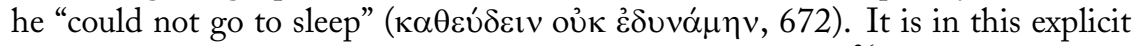
waking state that the messenger witnesses the miracle cure. ${ }^{36}$

Furthermore, Karion narrates his sleepless antics, describing how he mimicked a sacred snake to filch a pot of broth lying close by (672-695), and how he gave the god a flatulent reception (696-706) before settling down to spy on the supernatural treatments (707-715). Based on this unruly behavior, scholars who have recently written about the messenger speech have made the case that the comic witness awake is committing a religious infraction of some sort. Sineux (2006: 197-199) in particular has forcefully argued that this transgression is in fact the condition for the witnessing: he states that the slave's misbehavior stems from typical traits of the character type in Old Comedy, gluttony and unscrupulousness, which move him to disobey the order of the temple servant (669-671) and steal the pot (672-695). ${ }^{37}$ Thanks to this infraction, Sineux (2006: 210) maintains, the messenger can then "see" what others are forbidden to see, and becomes in this way a "mediator between the characters and the public," transgressing in their place. Although I do not deny the unruly nature of the slave's actions, I believe that the claim that Karion's spying is transgressive needs to be qualified. Of course, it is the prerogative of the comic playwright to subvert ritual practice for his own purposes, but this does not mean that his subversion cannot have a religious dimension as well. A closer look at the circumstances of the slave's witnessing, and a comparison with the other two classical repre-

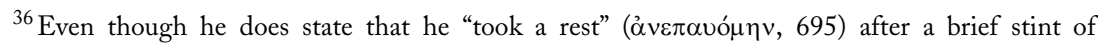
activity, which could be interpreted, as Sommerstein (2001: ad 695) remarks, as a sign that he did after all fall asleep, later on he makes clear that he is perceiving the events in a waking state, since he excitedly wakes up his master (740) when he sees Wealth regain his eyesight (738).

${ }^{37}$ For the slave's transgressive behavior, see also Fernández 2000: 75, and Tordoff 2012: 150.
} 
sentations of incubation, will reveal that his infraction is not as straightforward as it seems, and that it in fact finds parallels in the other representations.

According to Sineux, the presence of a witness awake in the space where incubation takes place, spying on the sleepers around him, would not be allowed in actual ritual practice. A comparable transgression in the Epidaurian collection (A11 LiDonnici) offers support for this reading: Aischines climbed a tree outside the sanctuary after the worshippers had gone to sleep in order to peep into the abaton, the space in which incubation took place, whose name itself, which literally means "the space where one cannot walk," implies a restricted sacred area. He then slipped and fell and badly hurt his eyes. Although the iama does not explicitly say so, this accident can be interpreted as punishment for his desire to spy on what takes place inside a space that is off-limits for those who are not incubating. But consequently Aischines "earnestly prayed to the

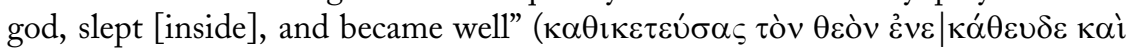

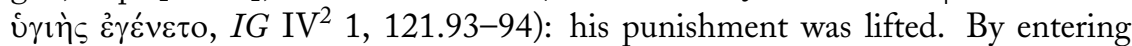
the space as a proper incubant and receiving the god's blessing, he could finally see what went on inside. Scholars have read this iama as an admonishment from the sanctuary about the proper behavior expected from visitors: no peeping into the space where incubation is performed. ${ }^{38}$

Yet an important distinction needs to be established between these two unlawful witnesses: while Aischines peeks into the abaton, Karion is already within the space, which, let it be said, was open to everyone-women, men, children, and even slaves-who wanted to practice incubation, as the iamata make clear. One could further argue that the slave's presence inside the space would be even more transgressive than Aischines' spying from the outside, since he is not ill and therefore in no need of incubation. Yet the slave makes clear at the beginning of his narrative that he participated in the preparatory rituals and laid down Wealth for incubation (653-663), actions that he states were followed

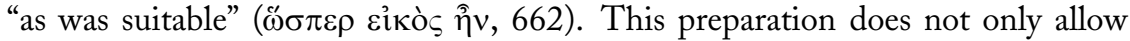
for his presence inside the space, but it also reveals that Karion is not the only non-incubant involved in the ritual, since his master Chremylos also performs the ritual and lies down to sleep with his slave next to Wealth (663). ${ }^{39}$

Yet, even if we discount the idea that the slave's presence in itself is an infraction, the problem of his behavior remains. The dramatic episode, however,

${ }^{38}$ A recent example is Petridou 2015: 183. Aischines' tale likewise recalls a iama (A4 LiDonnici) in which a woman who scoffed at the accounts of miracle cures was both punished and cured by the god in order to manifest his beneficial powers.

${ }^{39}$ Companions do appear in the Epidaurian iamata, and although the stories do not explicitly state that they slept in the abaton together with the patient, we do hear about servants preparing a bed for their mistress inside this space for the night (C2 [45] LiDonnici), and carrying their master outside in the morning (A17). Other companions mentioned by the iamata are parents of sick children (A5 and C1 [44]) and the attendants that accompany Sostrata on her voyage back home (B5 [25]). 
provides a useful guideline to qualify which actions of his may or may not be transgressive in the reactions of the pious wife of Chremylos, Karion's interlocutor. The wife scolds the slave for not fearing and respecting Asklepios (684) in response to his report of how he lunged for the pot of broth (682-686) and how he received the god with a malodorous fart (697-706). But she does not complain about the presence of the master and slave inside the space reserved for incubation; she only asks who else was incubating in the sanctuary (660-664). When Karion begins to relate the god's treatments, the mistress does not chide the slave for seeing what is not allowed, but for claiming to be able to see anything at all after covering his head with his cloak out of fear (710-715); it is the purported autopsy of his report, and not his unlawful spying, that earns him a rebuke.

Even if one remains unconvinced by the claim that Karion's witnessing is not an infraction, one must concede that what stands out about this witness, in contrast to Aischines, is that his infraction receives no comeuppance at all. Sineux (2006: 202-203) put forth the ingenious idea that the smoke that "bit" ( $\delta$ ' $\alpha \kappa v \varepsilon, 822)$ Karion's eyes in a later episode would have been the symbolic punishment for his transgressive witnessing. Blindness is indeed linked to a punishment of Asklepios in the comedy: for example, the slave recounts how the god harmed the eyesight of an unpopular politician who was incubating along with Wealth (716-726). Yet Sineux's reading does not hold if one takes into account the context of the speech: Karion is delivering a second messenger speech that announces the miraculous abundance inside his master's household that followed the entrance of Wealth (802-822). His momentary blindness, as he informs us, was caused by the smoke of lavish animal sacrifices inside (819-822). This smoke is thus the product of the household's new-found wealth, and becomes the explicit motivation for the slave's exit to announce the joyful news. The occasion would mark his blindness as a strange type of punishment indeed. ${ }^{40}$ But if one were to opt for a symbolic reading, perhaps it would be better to read Karion's blindness and good news in tandem with the return of Wealth from the sanctuary of Asklepios, in the episode that immediately precedes it, in which the formerly blind character enters with his eyesight fully restored to announce his new dispensation (771-781).

Thus far, I have made the case that Karion's transgression needs to be qualified if we are to understand his role as witness. Yet one could still argue that having a witness present during incubation, even if allowed, would still be unrealistic, and thus, that it should be ascribed to the comic fantasy. The fact that Epidaurian iamata register no account of a third party witnessing an incubation within the abaton would seem to confirm this. However, we do find

\footnotetext{
${ }^{40}$ If the "biting" smoke in Aristophanes brings to mind the action of animals associated with Asklepios, one should note that they bite in order to heal and not to harm: see for instance the goose of iama B23 (43) and the snake of C2 (45) LiDonnici.
} 


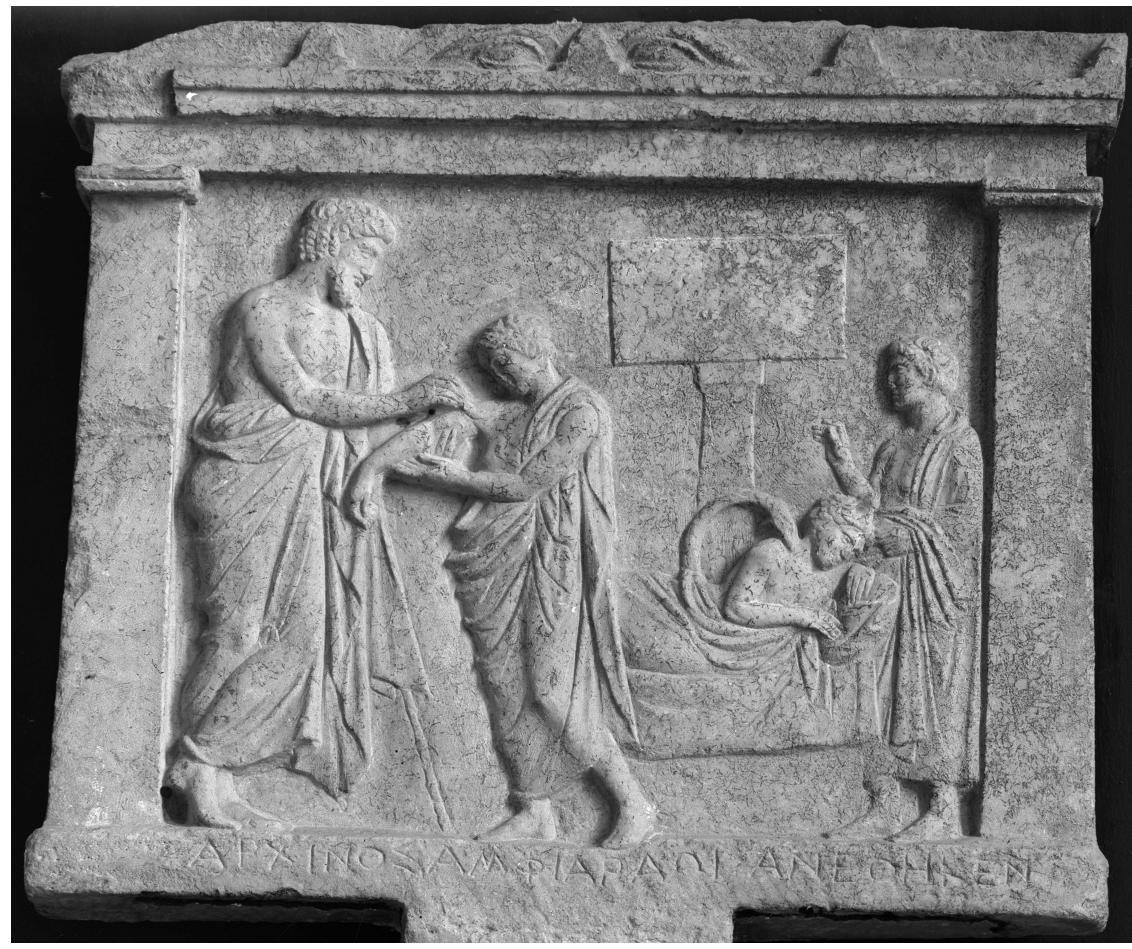

Fig. 1: Votive relief of Archinos from the sanctuary of Amphiaraos at Oropos, first half of the fourth century B.C.E. Athens, National Museum inv. 3369. Image courtesy of the German Archaeological Institute. Photograph: H. Wagner, DAI, Neg. D-DAI-ATHNM-3312. All rights reserved.

an example that comes very close: the experience of a priest at the sanctuary at Troezen who, when the sons of Asklepios could not finish an operation

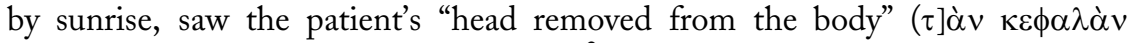

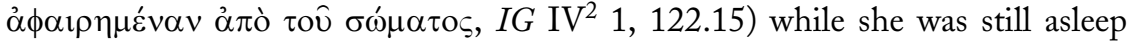
in the precinct (B3 [23]); yet one could argue that the identity of this particular witness would allow him access to the forbidden space. The collection also includes several miracle treatments which feature witnesses awake: the dream healing of a man sitting in the sanctuary, in full view of everyone (A 17), and the surgery of Sostrata, performed while the patient was wide awake and in full view of her attendants (B5 [25]), to which we will return. These cures take place outside the abaton. Nevertheless, there exists an example that matches what the comic iama portrays, and that is the votive relief of Archinos (fig. 1), dated to the first half of the fourth century в.C.E., which offers the viewer a direct representation of incubation from the perspective of a witness awake within the sanctuary, the very sight for which the peeping Aischines was pun- 
ished. I will turn to this remarkable representation at the end of the following section; suffice it to say that the idea that the witness awake is a transgressor runs counter to the purpose of the motif of the witness awake, which is to show that the god actively seeks to make his supernatural power manifest beyond the individual experience of incubation and the sacred space where it is practiced, as is proper for the aretalogical function of these accounts of divine power.

\section{b. The Perspective of the Witness Awake}

The treatment Karion sees in his waking state is no different from what the iamata consultants see in their dream visions: Asklepios wipes Wealth's eyelids, covers his face with a cloth, and then calls two serpents that lick his eyes back to health. In the iamata we also find the god treating patients with medicine, healing by touch, being aided by animals, etc. ${ }^{41}$ Thus, scholars have concluded that what the slave reports is basically what the patients are dreaming. Sineux (2006: 201) attributes this to the fact that Greek culture had "a conception of dreams according to which their content-a vision-possesses the same force of reality as that which one sees awake." This vivid quality of the vision endows it with "a kind of autonomy" with respect to the dreamer, which enables the possibility of imagining others having access to it. ${ }^{42}$

Yet the slave, as we have seen, has made clear that he is not asleep, and in this respect, it is important to keep in mind that the iamata are often careful to distinguish between dreams and waking visions: ${ }^{43}$ they not only use a formula to mark the start of incubatory sleep, as Karion does, but indicate those occasions in which a particular cure took place while the patient was awake (Uँ $\pi \alpha \rho)$, or in which the patients left with tangible proof of the god's actions after waking up, as in the case of Euhippos, who woke up to find in his hands a spearhead that the god had extracted from his jaw (A12). The iamata also indicate those instances in which witnesses saw the effects of the dream cure in the waking world: iama A17 features a simultaneous epiphany of the god, as an anthropomophic being inside the patient's dreams, and as an animal outside of it. ${ }^{44}$ In this tale, a man with an ulcerous toe was taken outside the abaton "during the day" ( $\mu \varepsilon \theta \dot{\alpha} \mu \varepsilon \rho \alpha$,

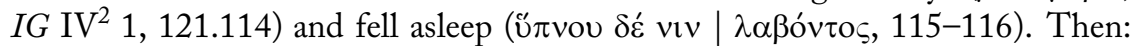

\footnotetext{
${ }^{41}$ For pharmacopeia, see iamata A4, A9, B20 (40), and B21 (41) LiDonnici; for healing by touch: A18, B11 (31), and B21 (41); for cleansing: A7 and B8 (28); for snake cures in incubation dreams: B19 (39) and B22 (42).

${ }^{42}$ In fact, as Hanson (1980: 1409) has mentioned, it is often difficult to distinguish a sleeper's dream from a waking vision in Greek literary accounts.

${ }^{43}$ See van Straten 1976: 4.

${ }^{44}$ For patients cured while awake, see iamata A16, A20, and B6 (26) LiDonnici. For patients who leave with tangible proofs of the intervention of the god, see A6, A12, A13, A14, B10 (30), and B21 (41). At other times, the iamata leave unclear the distinction between dream and reality: see LiDonnici 1995: 12-13.
} 
A snake ... came out of the abaton and healed his toe with its tongue .... When he

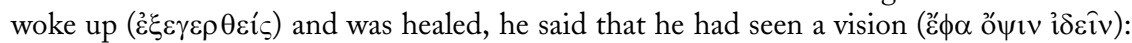

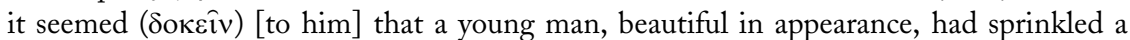
drug on his toe $\left(I G I^{2} 1,121.115-119\right){ }^{45}$

Once again, we find the formulas that mark the moment of falling asleep and waking, but in this case they serve to frame the simultaneous experience of the witnesses who are awake and that of the dreamer, whose vision is introduced with the familiar formulas. Dorati and Guidorizzi (1996: 360) call these narratives, which relate the effects of the dream vision in the waking world, "objective dreams," and interpret this distinction as the way in which the sanctuary makes concrete the subjective nature of the dream vision, not only to distinguish the incubatory experience from that of any other dream narrative, but also to mark them as authentic. ${ }^{46}$

This tendency towards the objective is already found at the time of Wealth, where it left its mark on the votive relief dedicated by Archinos to Amphiaraos (fig. 1). ${ }^{47}$ This representation follows the iconography of the incubatory reliefs outlined above: it depicts the moment of the efficacious treatment of the god, who stands to the left, presiding over the scene. The image of a votive relief in the background, as in the case of the Telemachos monument, marks the location as a sanctuary. ${ }^{48}$ To the right side of the relief, flanking the incubation scene, is the figure of the donor, Archinos, who stands with his right arm raised in a gesture of adoration. What is unusual about this relief, as scholars have remarked, is the choice to simultaneously portray both the waking and dreaming states of the treatment, in a manner that uncannily recalls iama A17, quoted above, which also involves a real snake and a dream healer. ${ }^{49}$ Archinos' dream vision, what "seemed to him" to happen (to use the iamata formula) after he fell asleep, is represented in the left half of the relief, where the god treats his shoulder. In the right half, Archinos is asleep while a sanctuary snake licks (or bites) the same spot the god is treating. ${ }^{50}$ One could argue that this scene is the

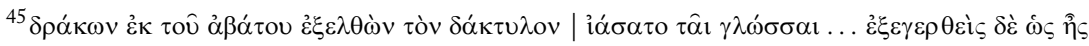

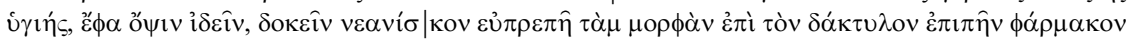
(translation mine).

${ }^{46}$ See also Petridou 2015: 192.

${ }^{47}$ Herzog 1931: 89, 91. See also van Straten 1976: 4; 1981: 124-125, no. 16.1; 1992: 257; Holtzmann 1984: 891-892. For recent comments on the relief in relation to the iamata, see Petsalis-Diomidis 2005: 209-210; Sineux 2007c: 203-206; Wickkiser 2008: 51; for a different view, cf. Platt 2011: 44-46.

${ }^{48}$ See Comella 2002: 52 and Petsalis-Diomidis 2005: 209.

${ }^{49}$ Herzog (1931: 89) seems to have been the first to compare the relief to the iamata. It should be noted that in the Epidaurian iamata animal healings are more common in cures that take place in the waking world (e.g., iamata A17, A20, B6 [26], B23 [43], and C1 [44] LiDonnici), although animals also appear in the dream visions, as mentioned above, 267, n. 41.

${ }^{50}$ I follow here the usual scholarly interpretation of the relief. Verity Platt (2011: 44-46) has recently questioned this reading, noting that there is no explicit indication that the three figures
} 
product of what the donor or the artist imagined took place outside the dream vision, yet these two still chose to portray the snake healing as independent from the donor's vision, as something that only a third-party witness, awake while the treatment was in progress, would have experienced. Through this choice, the outside viewer of the relief becomes an implicit witness, with full access to the miracle inside the sanctuary. This inclusion objectivizes and confirms Archinos' subjective experience by making the event concrete and visible to all outside the dream world, a typical strategy of the sanctuary narratives, as we have seen.

Unlike Archinos and iama A17, where we have parallel representations of subjective and objective perspectives on the cure, Aristophanes' comic iama gives us the perspective of a witness whose account subsumes the dream into the waking vision. In this way, the comic iama is, so to speak, "hyper-objectivized." Karion's unique experience could be ascribed to the comic fantasy, as a fictional and marvelous event that no one in reality would have experienced during incubations. Yet once again, a close parallel in the Epidaurian iamata brings into question just how fictional this comic representation could be: after Sostrata, afflicted by a false pregnancy, "saw no clear dream" while incubating at Epidauros, the god appeared to her when she was on her way back home, cut her belly, removed creatures from her insides, and sewed her up again (B5 [25]). This tale is remarkable in that it presents a sort of collective vision, introduced

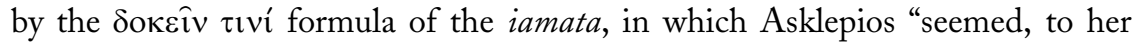

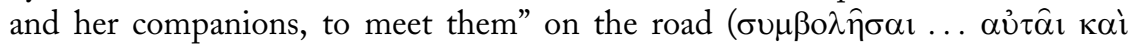

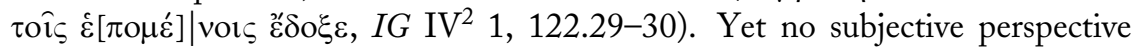
follows the formula: the iama employs direct discourse to report that the god inquired from Sostrata's party ( $\pi \alpha \rho$ ' $\alpha \hat{v} \tau \hat{\omega} v, I G I^{2} 1,122.30$ ) the condition she was in, and that the god performed the surgery at the roadside in view of her attendants. This type of treatment is more commonly featured in subjective accounts of dream cures in the Epidaurian collection, yet here we have a iama that is just as "hyper-objectivized" as the report of the comic witness. ${ }^{51}$

The purpose of these "objectivized" iamata is not merely to signal that the dream is authentic and give concrete proof of its effects; it also testifies to a way of conceiving the presence and power of the healing god, particularly in the light of epiphany. ${ }^{52}$ The existence of subjective and objective perspectives

displayed are actually Archinos. She suggests that the scenes on the relief, rather than constituting a simultaneous narrative of a single cure, could also stand for different ways of representing an epiphany. Her excellent analysis explores the challenges and ambiguities that arise from these portrayals. My take, however, is simpler: the god makes himself present unambiguously to all his worshippers in different situations, a certainty that is part of the motif of the witness awake. Platt (2011: 75-76) does not deny the latter, but considers it another facet of how elusive it is to represent epiphany.

${ }^{51}$ Examples of dream visions in which surgery is performed are iamata A13, B3 (23), B7 (27), and B10 (30) LiDonnici.

${ }^{52}$ For incubation as a form of epiphany, see most recently Petridou 2015: 171-193. 
of incubation might suggest that the god did not make himself accessible to everyone in the same fashion, that there were two levels of experiencing his power, and more specifically, that the dreamer had special access that was denied to those awake. But one must be careful not to distinguish the two perspectives in such a restrictive fashion, since, as we have seen, the god does not deny his presence to those who do not incubate; on the contrary, his dream cures can have a clear effect on the waking world, and can be witnessed by those who are awake. In brief, "objectifying" representations cannot be considered a limitation of divine presence, since the latter is still experienced; both accounts testify to a full epiphany of the god. In this respect, the therapeutic actions of animals in iama A17 and the Archinos relief are significant, since they are portrayed as manifestations of the supernatural healer. ${ }^{53}$

\section{CONCLUSION}

As Robert Parker (1996: 184) points out, "all gods and heroes ... traditionally had a friendly side; the novelty of Asklepios was to have no other." ${ }^{\text {4 }}$ The Epidaurian iamata repeatedly portray the god as making himself available to all, regardless of gender, age, or economic and social standing. ${ }^{55}$ In like manner, the image of the god transmitted by the motif of the witness awake is that he does not limit his manifestations to the dreams or visions of those who incubate inside the abaton, or even his sanctuaries, but allows others to have access to them as well. The motif thus testifies not only to the power of the god but also to his entirely approachable and even philanthropic character. The inclusion of these aspects of the god's persona, as Martzavou (2012: 190) has stated with respect to the Epidaurian iamata, are in part "a necessary element" for the creation of "a personal relationship with the divine," thereby making the god relatable to his human worshippers. ${ }^{56}$ In this respect, the motif of the witness awake becomes an important component of religious belief. Its use in the Epidaurian iamata and votive reliefs would therefore not come as a surprise, given the hand of the sanctuaries in compiling and rewriting narratives of incubation, and in authorizing the display of visual representations of the experience. Yet how can one explain the presence of the same motif, with the same religious purpose, in the comic iama of Aristophanes, a seemingly "transgressive" account outside the control of the sanctuaries? I believe one explanation could be the influence of the healing sanctuaries on the ways in which the experience of incubation was

\footnotetext{
${ }^{53}$ See Petridou 2015: 186. In this respect, it is curious how the iamata describe the action of animal healers in terms that best apply to human ones; thus, a dog is said to "have treated" $\left(\varepsilon \theta \varepsilon \rho \alpha \dot{\pi} \pi \varepsilon v \sigma \varepsilon, I G \mathrm{IV}^{2} 1,122.37\right)$ a patient, and a snake targets a specific ailment and body part, a tumor in a patient's hand, as if it were a surgeon (C2 [45] LiDonnici).

${ }^{54}$ Scholars often make this observation when it comes to Asklepios: see, for example, Sineux 2007a: 60-62, and Suárez de la Torre 2009: 40.

${ }^{55}$ Edelstein and Edelstein 1945: 2.116.

${ }^{56} \mathrm{Cf}$. also LiDonnici 1995: 68-69.
} 
commemorated and transmitted, affecting the cultural model itself, including its motifs, which would naturally be found in the textual and visual representations of the sanctuary and be adapted by the comic playwright to provide praise of the god in his own comic fashion. What Aristophanes contributes to the representation of the experience, through his use of the motif, is to take the sanctuary portrayal of the god to the limit, and have Asklepios allow the lowest and most scurrilous of witnesses the honor of assisting to his show of power, without any hindrance or punishment. ${ }^{57}$

Department of Classics

University of Maryland

7814 Regents Dr.

College Park, MD 20742

U.S.A.

fbarrene@umd.edu

BIBLIOGRAPHY

Aleshire, S. B. 1989. The Athenian Asklepieion: The People, Their Dedications, and the Inventories. Amsterdam.

Beschi, L. 1982. "Il rilievo di Telemachos ricompletato," Athens Annals of Archaeology 15: 31-43.

Clinton, K. 1994. "The Epidauria and the Arrival of Asclepius in Athens," in R. Hägg (ed.), Ancient Greek Cult Practice from the Epigraphical Evidence. Stockholm. 17-34.

Comella, A. 2002. I rilievi votivi greci di periodo arcaico e classico: Diffusione, ideologia, committenza. Bari.

Dillon, M. P. J. 1994. “The Didactic Nature of the Epidaurian Iamata," ZPE 101: 239-260.

Dorati, M. 2001. "Funzioni e motivi nelle stele di Epidauro e nelle raccolte cristiane di

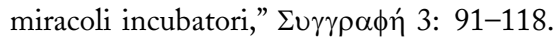

— and G. Guidorizzi. 1996. "La letteratura incubatoria," in O. Pecere and A. Stramaglia (eds.), La letteratura di consumo nel mondo greco-latino. Cassino. 343-371.

Downie, J. 2013. "Dream Hermeneutics in Aelius Aristides' Hieroi Logoi," in S. M. Oberhelman (ed.), Dreams, Healing, and Medicine in Greece: From Antiquity to the Present. Burlington, VT. 109-127.

— 2014. "Narrative and Divination: Artemidorus and Aelius Aristides," Arcbiv für Religionsgeschichte 15: 97-116.

\footnotetext{
${ }^{57} \mathrm{My}$ special gratitude goes out to Peter Agócs, who provided innumerable helpful comments that have done much to improve this article. I would also like to thank the anonymous readers for Phoenix, and Hanna Roisman and Joseph Roisman, for their valuable feedback. Special thanks are due as well to Alicia Montemayor, Rudy Le Menthéour, and especially Margherita Bolla, the curator of the Museo Maffeiano and Archaeological Museum of Verona, who patiently responded via email to all my inquiries about the relief in her collection. I am also immensely grateful to the Center for Hellenic Studies of Harvard University and its director Gregory Nagy, who provided a congenial forum for presenting an initial version of this article in their Research Symposium of the fall of 2015. All mistakes that remain are my own.
} 
Edelstein, E. J. and L. Edelstein. 1945. Asclepius: A Collection and Interpretation of the Testimonies. 2 vols. Baltimore.

Fernández, C. 2000. "Aspectos técnicos de la composición del discurso del mensajero en Plutos de Aristófanes (vv. 627-770)," Limes 12: 72-83.

Giovagnorio, F. 2015. Dediche votive private attiche del IV secolo a. C.: Il culto di Atena e delle divinità mediche. Oxford.

Hanson, J. S. 1980. "Dreams and Visions in the Graeco-Roman World and Early Christianity," $A N R W$ II.23.2: 1395-1427.

Herzog, R. 1931. Die Wunderheilungen von Epidauros: Ein Beitrag zur Geschichte der Medizin und der Religion. Leipzig.

Holtzmann, B. 1984. “Asklepios,” LIMC II.1: 863-897.

Johnston, S. I. 2008. Ancient Greek Divination. Oxford.

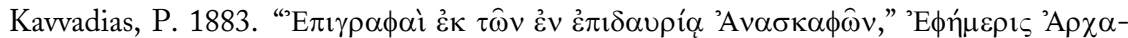
เодо $ү$ ıк'́. Athens. 197-238.

Lawton, C. 2009. "Attic Votive Reliefs and the Peloponnesian War," in O. Palagia (ed.), Art in Athens during the Peloponnesian War. Cambridge. 66-93.

LiDonnici, L. R. 1992. "Compositional Background of the Epidaurian 'Ió $\mu \alpha \tau \alpha, " A J P$ 113: $25-41$.

- 1995. The Epidaurian Miracle Inscriptions: Text, Translation and Commentary. Atlanta.

Martzavou, P. 2012. "Dream, Narrative, and the Construction of Hope in the 'Healing Miracles' of Epidauros," in A. Chaniotis, Unveiling Emotions: Sources and Methods for the Study of Emotions in the Greek World. Stuttgart. 177-204.

Mitropoulou, E. 1975. Kneeling Worshippers in Greek and Oriental Literature and Art. Athens.

Nutton, V. 2013. Ancient Medicine ${ }^{2}$. London.

Parker, R. 1996. Athenian Religion: A History. Oxford.

Petridou, G. 2015. Divine Epiphany in Greek Literature and Culture. Oxford.

Petsalis-Diomidis, A. 2005. "Amphiaraos Present: Images and Healing Pilgrimage in Classical Greece," in R. Maniura and R. Shepherd (eds.), Presence: The Inherence of the Prototype within Images and Other Objects. Burlington, VT. 205-229.

Platt, V. 2011. Facing the Gods: Epiphany and Representation in Graeco-Roman Art, Literature and Religion. Cambridge.

Roos, E. 1960. "De incubationis ritu per ludibrium apud Aristophanem detorto," OpAth 3: 55-97.

Sineux, P. 2006. "Une nuit à l'Asklépieion dans le Ploutos d'Aristophane: Un récit dans le théâtre pour l'étude du rite de l'incubation," Mètis N.s. 4: 193-210.

— 2007a. "Les récits de rêve dans les sanctuaires guérisseurs du monde grec: Des textes sous contrôle," Sociétés E̊ Représentations 23: 45-65.

— 2007b. "Dormir, rêver, montrer .... À propos de quelques 'représentations figurées' du rite de l'incubation sur les reliefs votifs des sanctuaires guérisseurs de l'Attique," Kentron 23: 11-29.

- 2007c. Amphiaraos: Guerrier, devin, et guérriseur. Paris.

Sommerstein, A. 2001. The Comedies of Aristophanes: Wealth. Warminster.

Suárez de la Torre, E. 2009. "Il mito e il culto di Asclepio in Grecia in età classica ed ellenistico-romana," in E. De Miro, G. Sfameni Gasparro, and V. Calì (eds.), Il culto 
di Asclepio nell' area mediterranea: atti del Convegno Internazionale, Agrigento, 20-22 novembre 2005. Rome. 27-48.

Sudhoff, K. 1926. "Handanlegung des Heilgottes auf attischen Weihetafeln: Reliefstudie," Archiv für Geschichte der Medizin 18: 235-250, plates IX-XII.

Tordoff, R. 2012. "Carion down the Piraeus: The Tragic Messenger Speech in Aristophanes' Wealth," in C. W. Marshall and G. Kovacs (eds.), No Laughing Matter: Studies in Athenian Comedy. Bristol. 141-157.

Vikela, E. 2004. "Greek Votive Offerings," ThesCRA I: 281-287.

van Straten, F. T. 1976. "Daikrates' Dream: A Votive Relief from Kos, and Some Other kat'onar Dedications," BABesch 51: 1-38.

— 1981. "Gifts for the Gods," in Versnel 1981: 65-151.

1992. "Votives and Votaries in Greek Sanctuaries," in A. Schachter and J. Bingen (eds.), Le Sanctuaire Grec. Geneva. 247-284.

Versnel, H. S. ed. 1981. Faith, Hope and Worship: Aspects of Religious Mentality in the Ancient World. Leiden.

von Ehrenheim, H. 2015. Greek Incubation Rituals in Classical and Hellenistic Times. Liège.

von Eickstedt, K.-V. 2001. Das Asklepieion im Piräus. Athens.

Wickkiser, B. L. 2008. Asklepios, Medicine, and the Politics of Healing in Fifth-Century Greece. Baltimore. 